DOI: 10.31393/reports-vnmedical-2021-25(2)-09

UDC: $616.314 .2-007.271-053.7: 617.52: 616-073.75$

\title{
REGRESSION MODELS OF INDIVIDUAL TELERADIOGRAPHIC INDICATORS ACCORDING TO RICKETTS METHOD IN UKRAINIAN YOUNG MEN AND YOUNG WOMEN WITH DIFFERENT FACE TYPES
}

Drachevska I. Yu.

National Pirogov Memorial Medical University, Vinnytsya, (Pyrogov street, 56, Vinnytsya, Ukraine, 21018)

Responsible for correspondence: e-mail: idra4evskaya@gmail.com

Received: February, 19, 2021; Accepted: March, 25, 2021

\begin{abstract}
Annotation. Anomalies of the dental-jaw system are one of the most difficult challenges of modern orthodontics, and accordingly require the use of modern and evidence-based therapy. To predict the results of treatment and proper planning of orthodontic interventions, a reliable tool in the hands of an orthodontist is cephalometric analysis by the Ricketts method. An important step in the successful implementation of this method of analysis is to conduct a study taking into account ethnicity, age, sex and the influence of facial type on teleradiographic indicators calculated by this method. The aim of the study is to build and analyze regression models of teleradiographic indicators used in the Ricketts method for Ukrainian young men and young women with orthognathic occlusion with different face types. Ricketts teleradiography was performed faor 49 young men and 76 young women with orthognathic occlusion. Cephalometric analysis was performed using OnyxCeph ${ }^{3}$ TM software, 3DPro version, Image Instruments GmbH, Germany (software license URSQ-1799). The division into facial types was performed by determining the morphological index of Garson. All indicators were divided into three groups: the first group included the main cephalometric points and measurements used in modern cephalometric analyzes Schwartz, Ricketts, Steiner, Roth-Jarabak, Burstone and Bjork and are parameters that usually do not change during surgery and orthodontic treatment; to the second group - metric dental-jaw characteristics by the Ricketts method by which surgical methods can change the length, width, angles and position of the jaws; to the third group - indicators according to the Ricketts method which characterize the position of each individual tooth relative to each other, cranial structures and the profile of the soft tissues of the face. Regression models of individual teleradiographic indicators are built using the license package "Statistica 6.0". Only reliable models with a coefficient of determination higher than 0.6 were subject to analysis. Of the 13 possible facial features, 9 models of teleradiographic indicators $\left(R^{2}=\right.$ from 0.691 to 0.834$)$ were included to the second group, depending on the indicators of the first group, and $9\left(R^{2}=\right.$ from 0.640 to 0.910 ) of the 15 possible models of indicators were included to the third group depending on the indicators of the first and second groups. In young men with a wide type of face, the constructed models of indicators included to the second group, depending on the indicators of the first group, most often include the distance Ar-Go (20.7\%), angle POr-NBa (13.8\%), distances N-S and S-E and the ratio $\mathrm{N}-\mathrm{S}$ :S-Ar' (10.3\% each); and to the models of indicators included in the third group depending on the indicators of the first and second groups - the angle N-CF-A (12.8\%), the distance Ar-Go (10.3\%), the distances N-CC and A-NPog and angle ANS- Xi-Pm, POr-ANSPNS and DC-Xi-Pm (7.7\% each). In young women with a very wide type of face out of 13 possible built only 2 models of teleradiographic indicators $\left(R^{2}=0.691\right.$ and 0.834$)$ which were included to the second group depending on the indicators of the first group and $5\left(R^{2}=\right.$ from 0.628 to 0.919$)$ of 15 possible models of indicators which entered the third group depending on the indicators of the first and second groups. In young women with a very wide type of face, the constructed models of indicators included in the third group, depending on the indicators of the first and second groups, most often include the distance Xi-Pm (18.2\%), as well as the distance P-PTV and angles MeGo-NPog and POr-CFXi (9.1\% each). In young women with a wide type of face from 13 possible 5 models of teleradiographic indicators $\left(R^{2}=\right.$ from 0.606 to 0.854$)$ which were included in the second group depending on indicators of the first group and 7 ( $R^{2}=$ from 0.607 to 0.888 ) from 15 possible models of indicators which were entered to the third group depending on the indicators of the first and second groups. In young women with a wide type of face, the constructed models of indicators included in the second group, depending on the indicators of the first group, most often include the distance Ar-Go (28.6\%) and the angle POrNBa and the ratio S-ar:ar-Go (14.3\%), and to the models of indicators included in the third group depending on the indicators of the first and second groups - the distances A-NPog and Xi-Pm and the angle NBa-PtG (10.3\% each).
\end{abstract}

Keywords: regression analysis, teleradiography, Ricketts cephalometry, young men and young women with orthognathic occlusion, facial types.

\section{Introduction}

Teleradiographic method of research has long been a reliable companion in the practice of dentistry. However, this routine method of instrumental research cannot independently provide the necessary information for treatment planning without choosing the cephalometric method of analysis.

Currently, more than a dozen methods of cephalometric analysis are known, among which, in particular, there are such common methods as Holdaway's, Burstone's [1],
Steiner's and Rickett's [21]

In addition, the methods of cephalometric analysis are successfully used in forensic medicine as a method of additional identification. Thus, in the work of M. Dmitriev et al. [9] proved the success of the use of cephalometric analysis by $\mathrm{C}$. Steiner of Ukrainian boys and girls; I. Perez et al. [23] after analyzing databases of 1296 people were able to build logistic models for 6 cephalometric indicators by Rickett's analysis with an accuracy of $60 \%$ to $70 \%$ to 
identify male Peruvians of Spanish descent.

In general, the method of cephalometric analysis is a clear example of the successful application of the anthropometric method for solving or finding solutions to problems of practical medicine. Researchers have thus identified correlations between different anthropometric indicators and features of the human body [20], or to identify regional specifics for these indicators [14]. In particular, the latter is a proven fact for the Ukrainian population and odontometric indicators.

Peculiarities of correlations of molar sizes with cephalometric indicators for both residents of the Western [13] and Southern regions of Ukraine [28] have been established. Features of regional indicators for children from different regions of the cube for cephalometric analysis by Rickett's established H. F. C. Suárez et al. [29, 30]. That is, even the regional origin of individuals has an impact on changes in odontometric and cephalometric parameters.

Racial and ethnic components are also key variables to consider. For example, a comparison of various data, including Rickett's cephalometric parameters in Bosnia, China and Nepal, found that $90 \%$ of Nepalese and $86.7 \%$ of Bosnians have the usual form of Sella turcica, while the Chinese have various forms of Sella turcica and the most common is flat variation (in $36.7 \%$ ). In addition, there were statistically significant differences in the length, depth and diameter of Sella turcica for residents of Nepal and China $(p<0.001, \quad p<0.01$ and $p<0.001$, respectively). Manifestations of sexual dimorphism have also been established [21].

Ukrainian scientists are currently actively conducting research in this area, taking into account these criteria and taking into account the type of human face $[18,19]$.

Thus, there is a need to work on the Ukrainian population, using such a common method of cephalometric analysis as Rickett's, and at least taking into account age, sex and face type.

The aim of the study is to build and analyze regression models of teleradiographic indicators used in the Rickett's method in Ukrainian young men and young women with orthognathic occlusion with different face types.

\section{Materials and methods}

With the help of the dental cone-beam tomograph Veraviewepocs 3D Morita (Japan) in the mode of cephalometric examination teleradiography was performed on 8 young men (aged 17 to 21 years) and 17 young women (aged 16 to 20 years) who had a physiological bite as close as possible to orthognathic (further orthognathic) which is defined on 11 points by M. G. Bushan, et al. [7]. From the database of the research center of National Pirogov Memorial Medical University, Vinnytsya selected 38 young men and 55 young women of the same age with orthognathic occlusion, who also underwent teleradiography followed by cephalometric analysis. Cephalometric analysis was performed using OnyxCeph ${ }^{3 \text { TM }}$ software, 3DPro version,
Image Instruments $\mathrm{GmbH}$, Germany (software license URSQ-1799).

Committee on Bioethics of National Pirogov Memorial Medical University, Vinnytsya (Minutes № 9 of November 21, 2019) found that the studies meet the bioethical and moral requirements of the Declaration of Helsinki, the Council of Europe Convention on Human Rights and Biomedicine (1977), the relevant WHO regulations and the laws of Ukraine according to Order of the Ministry of Health of Ukraine № 281 of November 1, 2000.

Cephalometric points were determined according to the recommendations of B. S. Phulari [24] and S. I. Doroshenko and E. A. Kulginsky [10].

Indicators determined by the Ricketts method were divided into three groups [12]. The first group includes the main cephalometric points and measurements used in modern cephalometric analyzes by Schwartz, Ricketts, Steiner, RothJarabak, Burstone and Bjork [11] and are parameters that usually do not change during surgical and orthodontic treatment; to the second group - metric dental-jaw characteristics by the Ricketts method in which the bone skeleton is formed and by which surgical methods it is possible to change the length, width, angles and position of the jaws; to the third group - indicators according to the Ricketts method which characterize the position of each individual tooth relative to each other, cranial structures and the profile of the soft tissues of the face.

The main cephalometric points and measurements included in the first group:

distance N-Se (length of the anterior part of the skull base according to Schwartz, distance Se-N) - the distance from the point $\mathrm{Se}$ to the point $\mathrm{N}(\mathrm{mm})$;

distance N-S (length of the front part of the skull base according to Roth-Jarabak) - distance from point $\mathrm{N}$ to point $S(\mathrm{~mm})$;

distance N-CC (anterior length of the base of the skull according to Ricketts) - the distance from point $\mathrm{N}$ to point $\mathrm{SS}$ $(\mathrm{mm})$;

distance S-E (length of the back of the skull base according to Steiner) - the distance from point $S$ to the structural point $\mathrm{E}$, which is located at the intersection of the perpendicular drawn from the point ppCond to the line S-N $(\mathrm{mm})$;

distance S-Ar (length of the lateral cranial base according to Roth-Jarabak) - the distance from point $\mathrm{S}$ to point $\operatorname{Ar}(\mathrm{mm})$;

distance P-PTV (according to Ricketts) - the distance from point $\mathrm{Po}$ to point $\mathrm{Pt}$, determined parallel to the Frankfurt plane $(\mathrm{mm})$;

Ar-Go distance (length of the mandibular branch according to Burstone) - the distance from the point Ar to the point tGo $(\mathrm{mm})$;

angle $\mathbf{H}$ (according to Schwartz) - the angle formed by the lines Po-Or and $\mathrm{Pn}\left({ }^{\circ}\right)$;

POr-NBa angle (Ricketts cranial deflection angle) - the angle formed by the Po-Or and $\mathrm{Ba}-\mathrm{N}$ lines $\left(^{\circ}\right.$ );

angle N-S-Ba (according to Bjork) - the angle formed by 
the lines S-N and S-Ba $\left(^{\circ}\right)$;

N-S-Ar angle (Bjork saddle angle) - the angle formed by the N-S and S-Ar lines $\left(^{\circ}\right)$;

distance S-Ar' (distance of the joint according to Bjork) - the distance from point $S$ to point $A r^{\prime}(\mathrm{mm})$;

the ratio N-S:S-Ar' - the ratio of the distances S-Ar' and $\mathrm{N}-\mathrm{S}$ in cephalometric analysis by Bjork;

S-ar:ar-Go ratio is the ratio of S-Ar and Ar-Go distances in Roth-Jarabak cephalometric analysis.

The main cephalometric points and measurements by the method of Ricketts [26], belonging to the second group: distance A-NPog - characterizes the position/distance of the anterior contour of the upper jaw to the line N-Pog $(\mathrm{mm})$;

angle ANS-Xi-Pm (angle of the lower face height) characterizes the height of the lower part of the face $\left(^{\circ}\right)$;

angle NPog-POr (depth of the face) - characterizes the horizontal position of the lower jaw relative to the Frankfurt plane $\left({ }^{\circ}\right)$;

angle NBa-PtG (angle of the facial axis) - characterizes the horizontal and vertical position of the mandible relative to the line $\mathrm{N}-\mathrm{Ba}$, determines the direction of growth of the mandible retrospectively, also expresses the relationship between facial depth and height $\left(^{\circ}\right)$;

angle MeGo-NPog (front cone) - characterizes the position of the mandibular plane relative to the front plane $\left.{ }^{\circ}\right)$;

angle MeGo-POr (angle of the mandibular plane) characterizes the angle of the mandibular plane relative to the Frankfurt plane, allows you to determine the presence of skeletal deep or open occlusion $\left(^{\circ}\right)$;

angle POr-NA (angle of depth of the upper jaw) characterizes the position of the anterior contour of the upper jaw in the boom plane $\left({ }^{\circ}\right)$;

angle N-CF-A (angle of height of the upper jaw) characterizes the height of the upper jaw $\left(^{\circ}\right)$;

POr-ANSPNS angle (angle of inclination of the maxillary plane) - characterizes the inclination of the upper jaw relative to the Frankfurt plane $\left(^{\circ}\right)$;

distance Go-CF (rear face height) - characterizes the rear face height $(\mathrm{mm})$;

angle POr-CFXi (angle of position of the branch of the mandible) - characterizes the position of the branch of the mandible $\left({ }^{\circ}\right)$;

angle DC-Xi-Pm (mandibular arch) - characterizes the angle formed by the longitudinal axes of the body and the condylar process of the mandible $\left(^{\circ}\right)$;

distance $\mathbf{X i - P m}$ (length of the lower jaw) - characterizes the length of the lower jaw $(\mathrm{mm})$.

The main cephalometric points and measurements by the method of Ricketts [26], belonging to the third group:

distance 6u-6I (molar ratio) - characterizes the position of the first molars relative to each other along the closing plane $(\mathrm{mm})$;

Ovrjet (horizontal ratio of incisors) - characterizes the position of the medial incisors of the upper and lower jaws relative to each other, along the closing plane $(\mathrm{mm})$;

Overbite (vertical ratio of incisors) - characterizes the position of the medial incisors of the upper and lower jaws relative to each other, along the vertical plane $(\mathrm{mm})$;

distance 11-OcP (extrusion of the lower medial incisors) - characterizes the position of the cutting edge of the medial incisors of the mandible relative to the closing plane $(\mathrm{mm})$;

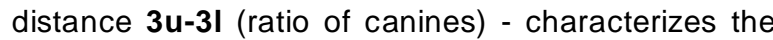
position of the canines of the upper and lower jaws relative to each other in the boom plane $(\mathrm{mm})$;

angle Max1-Mand1 (incisor angle) - characterizes the inclination of the upper and lower medial incisors relative to each other $\left({ }^{\circ}\right)$;

distance 6u-PTV (position of the upper large first angular tooth) - characterizes the position of the upper large first molars in the sagittal plane $(\mathrm{mm})$;

distance 1/-APog (protrusion of the lower medial incisors) - characterizes the position of the cutting edge of the medial incisors of the mandible in the sagittal plane relative to the line A-Pog $(\mathrm{mm})$;

distance 1u-APog (protrusion of the upper medial incisors) - characterizes the position of the cutting edge of the medial incisors of the upper jaw in the sagittal plane relative to the line A-Pog $(\mathrm{mm})$;

angle Mand1-APog (inclination of the lower medial incisors) - characterizes the inclination of the lower medial incisor to the line A-Pog $\left(^{\circ}\right)$;

angle Max1-APog (inclination of the upper medial incisors) - characterizes the inclination of the upper medial incisor to the line A-Pog $\left(^{\circ}\right)$;

distance $\mathbf{X} \mathbf{i}-\mathbf{O} \mathbf{C P}$ - characterizes the position of the closing plane relative to the point $\mathrm{Xi}$. Takes a positive value at a location above $\mathrm{Xi}$, and a negative value at a location below Xi (mm);

Li-NsPog' distance (soft tissue balance) - characterizes the position of the lower lip in the sagittal plane relative to the Ns-Pog' line (mm);

distance ANS-sto (length of the upper lip) - characterizes the height/length of the upper lip $(\mathrm{mm})$;

sto-Ocp distance - characterizes the position of the closing plane relative to the point of closing the lips. Takes a positive value when located above the point sto and a negative value if lower $(\mathrm{mm})$.

To divide into facial types, the morphological index of Garson was determined [25]. The following distribution by face types was established: young men - 5 with a very wide face, 22 with a wide face, 11 with a medium face, 8 with a narrow face; young women - 25 with a very wide face, 25 with a wide face, 10 with a medium face, 12 with a narrow face. Taking into account this distribution for further correct modeling of teleradiographic indicators by the Ricketts method, we studied only young men with a wide face and young women with a very wide and wide face.

Regression models of individual teleradiographic indicators, which are included in the second group depending on the indicators of the first group and which 
are included in the third group depending on the indicators of the first and second groups are built in the license package "Statistica 6.0".

\section{Results. Discussion}

Simulation of teleradiographic indicators by the Ricketts method, which were included in the second group depending on the indicators of the first group in young men with a wide type of face.

The models have the form of the following linear equations:

angle ANS-Xi-Pm (young men with a wide face type) = $72.27-1.704 \times \mathrm{N}-\mathrm{S}+2.637 \times \mathrm{S}-\mathrm{E}+9.939 \times \mathrm{N}-\mathrm{S}: \mathrm{S}-\mathrm{Ar} \times$ $\left(R^{2}=0.691 ; \quad F_{(3.18)}=13.43 ; \quad p<0.0001 ;\right.$ Std.Error of estimate $=2.970$ );

angle NPog-POr (young men with a wide face type) = $38.56+0.524 \times$ Ar-Go $+0.600 \times$ POr-NBa $-0.524 \times \mathrm{S}-\mathrm{E}+$ $0.146 \times \mathrm{N}-\mathrm{S}-\mathrm{Ba}\left(R^{2}=0.795 ; F_{(4.17)}=16.49 ; p<0.0000 ;\right.$ Std. Error of estimate=1.920);

angle NBa-PtG (young men with a wide face type) = $38.02+0.485 \times$ Ar-Go+ $0.774 \times$ N-S $-0.553 \times$ POr-NBa $0.50 \times$ S-E $\left(R^{2}=0.813 ; F_{(4.17)}=18.52 ; p<0.0000 ;\right.$ Std. Error of estimate $=2.318)$;

angle MeGo-POr (young men with a wide face type) = $106.2-0.851 \times$ Ar-Go - 2.295 x N-S:S-Ar' 0.488 x N-S $\left(R^{2}=0.834 ; \quad F_{(3.18)}=30.19 ; \quad p<0.0000 ;\right.$ Std. Error of estimate $=2.569$ );

angle POr-NA (young men with a wide face type) = $88.96-0.232 \times \mathrm{N}-\mathrm{S}: \mathrm{S}-\mathrm{Ar}^{\prime}+0.659 \times \mathrm{POr}-\mathrm{NBa}\left(R^{2}=0.664\right.$; $F_{(2.19)}=18.80 ; p<0.0000 ;$ Std. Error of estimate $\left.=2.085\right)$;

angle $\mathbf{N}-\boldsymbol{C F}$-A (young men with a wide face type) $=57.24$ $-0.303 \times$ Ar-Go $+0.406 \times \mathrm{H}-0.483 \times \mathrm{N}-\mathrm{S}+0.309 \times \mathrm{S}-\mathrm{Ar}$ $\left(R^{2}=0.752 ; \quad F_{(4.17)}=12.86 ; \quad p<0.0001 ;\right.$ Std. Error of estimate $=1.670$ );

angle POr-ANSPNS (young men with a wide face type) $=76.10-0.969 \times \mathrm{H}-0.282 \times$ Ar-Go $+0.225 \times \mathrm{N}-\mathrm{S}-\mathrm{Ba}$ $\left(R^{2}=0.788 ; \quad F_{(3.18)}=22.26 ; \quad p<0.0000 ;\right.$ Std. Error of estimate $=1.826)$;

distance Go-CF (young men with a wide face type) = $14.47+0.668 \times$ Ar-Go $-0.474 \times$ P-PTV $\left(R^{2}=0.801\right.$; $F_{(2.19)}=38.20 ; p<0.0000 ;$ Std. Error of estimate $\left.=2.032\right)$;

angle POr-CFXi (young men with a wide face type) = $78.09-0.241 \times$ S-ar:ar-Go + 0.725 x POr-NBa - $0.185 \times$ N-S$\mathrm{Ar}+0.292 \times \mathrm{N}-\mathrm{CC}\left(R^{2}=0.771 ; F_{(4.17)}=14.34 ; p<0.0000\right.$; Std. Error of estimate $=1.866)$;

where, here and hereafter, $R^{2}$ is the coefficient of determination; $F_{(\text {(!!!) }}=$ !!.!! - critical (!..!!) and obtained (!!.!!) value of Fisher's criterion; St. Error of estimate - standard error of the standardized regression coefficient.

The coefficients of determination of the regression equations of the magnitude of the angles A-NPog, MeGoNPog and DC-Xi-Pm and the magnitude of the distance $\mathrm{Xi}-$ $\mathrm{Pm}$ in young men with a wide face type are from 0.124 to 0.583 and therefore have no practical significance.

Thus, out of 13 possible young men with a wide type of face, 9 reliable models of teleradiographic indicators were constructed according to the Ricketts method with a coefficient of determination higher than 0.6 , which were included in the second group depending on the indicators of the first group $\left(\mathrm{R}^{2}=\right.$ from 0.691 to 0.834$)$. The most commonly constructed models include: the value of the distance Ar-Go $(20.7 \%)$, the value of the angle POr-NBa $(13.8 \%)$, the value of the distances N-S and S-E and the ratio N-S:S-Ar' (10.3\% each), and the distance N-CC and angles $\mathrm{H}$ and $\mathrm{N}-\mathrm{S}-\mathrm{Ba}$ (6.9\% each).

Simulation of teleradiographic indicators by the Ricketts method, which were included in the second group depending on the indicators of the first group in young women with a very wide type of face.

The models have the form of the following linear equations:

distance Go-CF (young women with a very wide face type $)=-8.538+0.800 \times$ Ar-Go $+0.476 \times$ S-Ar $-0.496 \times \mathrm{P}-\mathrm{PTV}$ $\left(R^{2}=0.939 ; \quad F_{(3.21)}=107.4 ; \quad p<0.0000 ;\right.$ Std. Error of estimate=2.172);

distance $\mathbf{X i - P m}$ (young women with a very wide face type $)=-1.068+0.899 \times \mathrm{N}-\mathrm{Se}+0.497 \times \mathrm{S}-\mathrm{E}\left(R^{2}=0.859\right.$; $F_{(2.22)}=67.26 ; p<0.0000 ;$ Std. Error of estimate=2.841).

The regression equation for the MeGo-NPog angle in young women with a very wide face type has not been constructed at all. Coefficients of determination of regression equations of the size of angles A-NPog, ANSXi-PM, NPog-POR, NBa-PtG, MeGo-POr, POR-NA, N-CF-A, POR-ANSPNS, POR-CFXi and DC-Xi-Pm in young women with a very wide type of face is from 0.130 to 0.574 and therefore have no practical significance.

Thus, in young women with a very wide type of face out of 13 possible, only 2 reliable models of teleradiographic indicators were built according to the Ricketts method with a coefficient of determination higher than 0.6 which were included in the second group depending on the indicators of the first group $\left(\mathrm{R}^{2}=0.691\right.$ and 0.834$)$.

Modeling of teleradiographic indicators by the Ricketts method, which were included in the second group depending on the indicators of the first group in young women with a wide type of face.

The models have the form of the following linear equations:

angle ANS-Xi-Pm (young women with a wide face type) $=89.67+0.583 \times$ S-ar:ar-Go $-0.988 \times \mathrm{H}+0.562 \times$ Ar-Go $0.615 \times \operatorname{S}-\operatorname{Ar}\left(R^{2}=0.606 ; F_{(4.19)}=7.32 ; p<0.0010 ;\right.$ Std. Error of estimate $=2.340$ );

angle NPog-POr (young women with a wide face type) $=91.86-2.976 \times \mathrm{N}-\mathrm{S}: \mathrm{S}-\mathrm{Ar}^{\prime}-0.173 \times \mathrm{P}-\mathrm{PTV}\left(R^{2}=0.829\right.$; $F_{(2.7)}=16.96 ; p<0.0021$; Std. Error of estimate $\left.=0.946\right)$;

angle MeGo-POr (young women with a wide face type) $=44.81-0.636 \times \mathrm{Ar}-\mathrm{Go}-0.688 \times \mathrm{POr}-\mathrm{NBa}+0.446 \times \mathrm{N}-\mathrm{CC}$ $\left(R^{2}=0.685 ; \quad F_{(3.20)}=14.47 ; \quad p<0.0000 ;\right.$ Std. Error of estimate $=2.593$ );

distance Go-CF (young women with a wide face type) = $-20.14+1.305 \times$ Ar-Go + $0.330 \times$ S-ar:ar-Go $\left(R^{2}=0.854\right.$; $F_{(2.21)}=61.65 ; p<0.0000 ;$ Std. Error of estimate $\left.=3.104\right)$; 
distance $\mathrm{Xi-Pm}$ (young women with a wide face type) = $-11.31+0.707 \times \mathrm{Ar}-\mathrm{Go}+0.706 \times \mathrm{POr}-\mathrm{NBa}+0.198 \times \mathrm{N}-\mathrm{S}-\mathrm{Ba}$ $\left(R^{2}=0.824 ; \quad F_{(3.20)}=31.26 ; \quad p<0.0000 ;\right.$ Std. Error of estimate $=2.434$ ).

The regression equation for the magnitude of the ANPog angle in young women with a wide face type is not constructed at all. The coefficients of determination of the regression equations of the magnitude of the angles NBaPtG, MeGo-POr, POR-NA, N-CF-A, POR-ANSPNS, POR-CFXi and DC-Xi-Pm in young women with a wide face type are from 0.110 to 0.516 and therefore have no practical significance.

Thus, in young women with a wide face type out of 13 possible, 5 reliable models of teleradiographic indicators were constructed according to the Ricketts method with a coefficient of determination higher than 0.6 which were included in the second group depending on the indicators of the first group $\left(\mathrm{R}^{2}=\right.$ from 0.606 to 0.854$)$. The constructed models most often include: the value of the distance Ar-Go $(28.6 \%)$ and the value of the angle POr-NBa and the ratio S-ar:ar-Go (14.3\% each).

Modeling of teleradiographic indicators by the Ricketts method, which were included in the third group depending on the indicators of the first and second groups in young men with a wide type of face.

The models have the form of the following linear equations:

distance 6u-6I(OcP) (young men with a wide face type) $=-36.59+0.243 \times \mathrm{N}-\mathrm{S}-\mathrm{Ar}+0.272 \times \mathrm{N}-\mathrm{S}+0.255 \times \mathrm{A}-\mathrm{NPog}-$ $0.146 \times \mathrm{N}-\mathrm{S}-\mathrm{Ba}+0.074 \times$ Ar-Go $\left(R^{2}=0.640 ; F_{(5.16)}=5.68\right.$; $p<0.0034$; Std. Error of estimate $=0.977$ );

distance Overbite (young men with a wide face type) = $-7.208-0.185 \times$ Ar-Go + $0.254 \times \mathrm{N}-\mathrm{Se}+0.184 \times \mathrm{A}-\mathrm{NPog}+$ $0.049 \times$ DC-Xi-Pm $\left(R^{2}=0.697 ; F_{(4.17)}=9.77 ; p<0.0003\right.$; Std. Error of estimate $=0.746)$;

angle Max1-Mand1 (юнаки з широким типом обличчя) $=-14.61+1.539 \times$ N-CF-A + 1.148 x POr-CFXi - $0.725 \times$ $\mathrm{Ar}-\mathrm{Go}+0.327 \times \mathrm{DC}-\mathrm{Xi}-\mathrm{Pm} \quad\left(R^{2}=0.745 ; F_{(4.17)}=12.39\right.$; $p<0.0001$; Std. Error of estimate $=3.410)$;

distance 6u-PTV (young men with a wide face type) = $5.164+0.925 \times$ NPog-POr $-0.932 \times$ N-CF-A + $0.529 \times \mathrm{N}-\mathrm{CC}$ - 0.494 x NBa-PtG $\left(R^{2}=0.910 ; F_{(4.17)}=43.21 ; p<0.0000\right.$; Std. Error of estimate $=1.427)$;

distance 1/-APog (young men with a wide face type) = $31.38-0.221 \times \mathrm{N}-\mathrm{CC}-0.373 \times \mathrm{N}-\mathrm{CF}-\mathrm{A}+0.185 \times \mathrm{ANS}-\mathrm{Xi}-\mathrm{Pm}$ - $0.151 \times$ POr-NBa $\left(R^{2}=0.640 ; F_{(4.17)}=7.54 ; p<0.0011\right.$; Std.Error of estimate $=0.915)$;

distance 1u-APog (young men with a wide face type) = $58.80-0.174$ x N-CC - 0.638 x N-CF-A - 0.111 x DC-Xi-Pm $0.150 \times$ POr-CFXi + $0.161 \times$ ANS-Xi-Pm $\left(R^{2}=0.664\right.$; $F_{(5.16)}=6.32 ; p<0.0020$; Std. Error of estimate=0.990);

angle Max1-APog (young men with a wide face type) = $151.8-0.665 \times \mathrm{H}+1.219 \times$ Ar-Go $-1.016 \times$ Go-CF $-0.672 \times$ NPog-POr - $0.449 \times$ POr-ANSPNS $\left(R^{2}=0.888 ; F_{(5.16)}\right)=25.27$; $p<0.0000$; Std. Error of estimate $=1.253$ );

distance $\mathbf{X i - O C P}$ (young men with a wide face type) =
$18.96-1.255 \times \mathrm{N}-\mathrm{S}+0.849 \times \mathrm{N}-\mathrm{Se}+0.474 \times$ POr-ANSPNS $+0.259 \times$ ANS-Xi-Pm $\left(R^{2}=0.706 ; F_{(4.17)}=10.19 ; p<0.0002\right.$; Std. Error of estimate $=1.854)$;

distance Li-NsPog' (young men with a wide face type) $=37.41+0.371 \times$ A-NPog $+0.178 \times$ POr-ANSPNS $-0.288 \times$ $\mathrm{Xi}-\mathrm{Pm}-0.356$ x N-CF-A $\left(R^{2}=0.725 ; F_{(4.17)}=11.19 ; p<0.0001\right.$; Std. Error of estimate $=1.363$ ).

The coefficients for determining the regression equations of the distances Ovrjet, 1I-OcP, 3u-3I (OcP), ANS-sto and sto-OcP and the values of the Mand1-APog angle in young men with a wide face type are from 0.324 to 0.590 and therefore have no practical significance.

Thus, 9 reliable models of Ricketts teleradiography indicators with a coefficient of determination higher than 0.6 , which were included in the third group depending on the indicators of the first and second groups $\left(\mathrm{R}^{2}=\right.$ from 0.640 to 0.910 ), were constructed from 15 possible for young men with a wide face type. The constructed models most often include: the value of the angle N-CF-A (12.8\%), the value of the distance Ar-Go (10.3\%), the value of the distances N-CC and A-NPog and the angles ANS-Xi-Pm, POr-ANSPNS and DC-Xi-Pm (7.7\% each), as well as NSe and NS distances and NPog-POr angles and POr-CFXi angle (6.9 \% each).

Modeling of teleradiographic indicators by the Ricketts method, which were included in the third group depending on the indicators of the first and second groups in young women with a very wide face type.

The models have the form of the following linear equations:

distance Ovrjet (young women with a very wide face type $)=5.576+0.020 \times$ S-ar:ar-Go $-0.058 \times \mathrm{Ar}-\mathrm{Go}+0.033$ ? Xi$\mathrm{Pm}-0.037 \times \mathrm{NBa}-\mathrm{PtG}\left(R^{2}=0.645 ; F_{(4.20)}=9.07 ; p<0.0002\right.$; Std. Error of estimate $=0.297)$;

angle Max1-Mand1 (young women with a very wide face type $)=356.0-2.473 \times$ MeGo-NPog $-2.852 \times$ A-NPog $1.840 \times$ P-PTV $-1.483 \times$ Xi-Pm $-1.215 \times$ N-CF-A + $0.792 \times$ Go-CF $\left(R^{2}=0.745 ; F_{(6.18)}=8.79 ; p<0.0002 ;\right.$ Std. Error of estimate $=4.955$ );

distance 6u-PTV (young women with a very wide face type $)=-50.51+0.553 \times$ POr-CFXi $+0.219 \times$ Xi-Pm +0.509 x POr-NBa $\left(R^{2}=0.919 ; F_{(3.21)}=79.28 ; p<0.0000 ;\right.$ Std. Error of estimate $=1.143$ );

distance 1u-APog (young women with a very wide face type) $=-20.60+0.263 \times$ MeGo-NPog $+0.485 \times$ P-PTV + $0.393 \times$ POr-NA $-0.275 \times$ POr-CFXi $+0.170 \times \mathrm{N}-\mathrm{CC}$ $\left(R^{2}=0.628 ; \quad F_{(5.19)}=6.42 ; \quad p<0.0012 ; \quad\right.$ Std. Error of estimate $=1.310$ );

distance ANS-sto (young women with a very wide face type $)=19.03+0.312 \times \mathrm{Xi}-\mathrm{Pm}+0.199 \times$ ANS-Xi-Pm -0.329 $x$ POr-ANSPNS - 0.278 x NPog-POr $\left(R^{2}=0.853 ; F_{(4.20)}=29.01\right.$; $p<0.0000$; Std. Error of estimate $=1.077$ ).

Coefficients of determination of regression equations of values of distances $6 \mathrm{u}-6 \mathrm{I}$ (OcP), Overbite, 1I-OcP, 3u-3I (OcP), 1l-APog, Xi-OcP, Li-NsPog and sto-OcP and values of angles Mand1-APog and Max1-APog in young women 
with a very wide face type is between 0.106 and 0.599 and therefore has no practical significance.

Thus, in young women with a very wide type of face out of 15 possible, 5 reliable models of teleradiographic indicators were built according to the Ricketts method with a coefficient of determination higher than 0.6 which were included in the third group depending on the indicators of the first and second groups $\left(R^{2}=\right.$ from 0.628 to 0.919$)$. The constructed models most often include: the value of the distance Xi-Pm (18.2\%) and the value of the distance $\mathrm{P}$ PTV and the angles MeGo-NPog and POr-CFXi $(9.1 \%$ each).

Modeling of teleradiographic indicators by the Ricketts method, which were included in the third group depending on the indicators of the first and second groups in young women with a wide type of face.

The models have the form of the following linear equations:

distance 6u-6I(OcP) (young women with a wide face type $)=10.97+0.239 \times$ A-NPog $-0.257 \times$ ANS-Xi-Pm +0.095 x Go-CF + 0.138 x MeGo-Por - 0.111 x H $\left(R^{2}=0.607\right.$; $F_{(5.18)}=5.56 ; p<0.0029$; Std. Error of estimate=0.699);

distance 1I-OcP (young women with a wide face type)= $-53.94+0.338 \times \mathrm{NBa}-\mathrm{PtG}+0.313 \times \mathrm{N}-\mathrm{CF}-\mathrm{A}-0.151 \times \mathrm{POr}-$ ANSPNS + 0.119 x N-CC $\left(R^{2}=0.625 ; F_{(4.19)}=7.91 ; p<0.0006\right.$; Std.Error of estimate $=0.851$ ):

distance 6u-PTV (young women with a wide face type) $=-43.80+0.409 \times$ POr-CFXi $+0.659 \times$ Xi-Pm - $0.201 \times$ Go$\mathrm{CF}+0.263 \times$ A-NPog $\left(R^{2}=0.888 ; F_{(4.19)}=37.82 ; p<0.0000\right.$; Std.Error of estimate $=1.384)$;

angle Mand1-APog (young women with a wide face type $)=-162.9+12.24 \times \mathrm{N}-\mathrm{S}: \mathrm{S}-\mathrm{Ar}+0.871 \times \mathrm{N}-\mathrm{S}-\mathrm{Ar}+0.355$ x N-CC + 0.215 x S-ar:ar-Go $\left(R^{2}=0.609 ; F_{(4.19)}=7.41\right.$; $p<0.0009$; Std.Error of estimate $=2.535$ );

distance $\mathrm{Xi}-\mathrm{OCP}$ (young women with a wide face type) $=-24.24-0.432 \times \mathrm{NBa}-\mathrm{PtG}+0.667 \times$ MeGo-NPog $-0.471 \times$ $\mathrm{S}-\mathrm{E}+0.404 \times \mathrm{Xi}-\mathrm{Pm}\left(\mathrm{R}^{2}=0.794 ; \mathrm{F}_{(4.19)}=18.32 ; \mathrm{p}<0.0000\right.$; Std.Error of estimate $=1.673)$;

distance Li-NsPog' (young women with a wide face type $)=37.76+0.745 \times \mathrm{A}-\mathrm{NPog}+0.267 \times \mathrm{P}-\mathrm{PTV}-0.348 \times \mathrm{N}-$ CF-A $-0.273 \times \mathrm{NBa}-\mathrm{PtG}+0.105 \times \mathrm{N}-\mathrm{S}-\mathrm{Ba}\left(R^{2}=0.876\right.$; $F_{(5.18)}=25.38 ; p<0.0000 ;$ Std. Error of estimate $\left.=1.011\right)$;

distance ANS-sto (young women with a wide face type) $=11.61+0.259 \times$ ANS-Xi-Pm $+0.465 \times$ Xi-Pm $-0.324 \times$ NPog-POr $\left(R^{2}=0.840 ; F_{(3.20)}=35.04 ; p<0.0000 ;\right.$ Std. Error of estimate $=1.174)$.

The regression equation for the Overbite distance in young women with a wide face type has not been constructed at all. The coefficients of determination of the regression equations of the distances Ovrjet, 3u-3I (OcP), 1l-APog, 1u-APog and sto-OcP and the values of the angles Max1-Mand1 and Max1-APog in young women with a wide face type are from 0.215 to 0.542 and therefore not have practical significance.

Thus, in young women with a wide face type, out of 15 possible, 7 reliable models of teleradiographic indicators were constructed according to the Ricketts method with a coefficient of determination higher than 0.6 , which were included in the third group depending on the indicators of the first and second groups $\left(\mathrm{R}^{2}=0.607\right.$ to 0.888$)$. The constructed models most often include: the magnitude of the distances A-NPog and Xi-Pm and the angle NBa-PtG (10.3\% each), as well as the magnitude of the distances $\mathrm{N}-\mathrm{CC}$ and Go-CF and the angles ANS-Xi-Pm and N-CF-A (6.9\% each).

In the studies of Chernysh A. V. [8] in boys and girls with orthognathic occlusion without division into facial types according to the Ricketts method, only 2 models of teleradiographic indicators were included in the second group depending on the indicators of the first group (respectively $R^{2}=0.884$ and 0.928 and $R 2=0.735$ and 0.719 ), as well as 7 in boys and 5 in girls models of indicators included in the third group depending on the indicators of the first and second groups (respectively R2 = from 0.568 to 0.887 , and $R^{2}=$ from 0.515 to 0.880 ). Both boys and girls most often include the B-Pog distance in the constructed models of indicators included in the third group, depending on the indicators of the first and second groups ( $11.1 \%$ for boys and $15.6 \%$ for girls)

M. Ab Talib et al. [1] found statistically significant differences in such indicators of Ricketts cephalometric analysis as the index of the lower lip to the $E$ line, the thickness of both the upper and lower lip and the nasolabial angle for Malays men and women.

R. Al-Azemi and J. Artun [2] in the study of cephalometric norms by Ricketts for the population of Kuwait found almost no significant differences from the normative indicators. Some differences were found only for the skeletal width of the teeth and their ratios. Also, no sexual characteristics of the studied indicators were revealed. Also close to the norm were the norm data obtained during a study of the population of Pakistan [16].

In a study of a Peruvian sample of Spanish origin, the authors found statistically significant differences in 7 of the 12 studied cephalometric parameters according to Ricketts. In general, the normative indicators were quite close to the Ricketts data [22].

15 measurements according to the Ricketts analysis were performed to study 160 teleradiograms of residents of Saudi Arabia. The statistical analysis of the obtained data revealed insignificant manifestations of sexual dimorphism - 3 studied indicators were higher in women than in men; however, no significant differences were found between the population of Saudi Arabia and the Ricketts control data [3].

In another study, also conducted on a sample of residents of Saudi Arabia, the authors confirmed the presence of manifestations of sexual dimorphism. In particular, such differences were found for the indicators of the lower incisor to A-Pog and lower lip to $E$ plane of the lower lip $(p<0.05)$ and the ratio of the distal position of the mandible to the vertical plane of the pterygoid process 
$(p<0.001)$ which were greater in men [27].

Data from Korean scientists suggest that the Ricketts test can be used successfully for Koreans from the age of 9. It is important to take into account sex and early age of use of treatment by this method of analysis [4].

Nigerians were found to have higher cephalometric data in the Steiner, Ricketts, Burstone, and Holdaway analyzes than the control values, except for the Z-angle, which was lower than the control. Manifestations of sexual dimorphism were also detected among 8 studied indicators [15].

Compared with the Ricketts norm, the population of Northeast China has higher protrusions of the upper and lower lip [17].

Brazilian researchers found a correlation between Ricketts-Faltin cephalometric parameters and vertical facial size in the analysis of teleradiograms of 45 Brazilian children with treatment starting at 7 years and ending treatment at 13 years [5].

In addition, the association between facial types determined by morphological index and cephalometric parameters by the Ricketts method was reported by a team of researchers led by G. D. P. Bolzan [6].

Creating a database of normative cephalometric indicators in Ukraine in accordance with the Ricketts methodology will provide dental care at a modern, individual level, taking into account not only the age, sex and ethnicity of the person, but also his face type.

\section{Conclusions and prospects for further development}

1. In young men with a wide type of face according to the Ricketts method, 9 reliable models of teleradiographic indicators with a coefficient of determination higher than

\section{References}

[1] Ab Talib, M., Aziz, A. S. N., Alam, M. K., Basri, R., Purmal, K., \& Rahman, S. A. (2014). Linear and angular cephalometric measurement of lip morphology among Malaysian Malay. International Medical Journal, 21(1), 41-44.

[2] Al-Azemi, R., \& Artun, J. (2012). Posteroanterior cephalometric norms for an adolescent Kuwaiti population. The European Journal of Orthodontics, 34(3), 312-317. https://doi.org/ 10.1093/ejo/cjr007

[3] Alroudhan, I. E., Kundi, I., Alam, M. K., Albalawe, M. A., Alsharari, K. N., \& Alrwaili, A. M. (2021). Evaluation of craniofacial morphometry of northern Saudi Arabian population, using Rickett's analysis: A descriptive cross-sectional study. Journal of International Oral Health, 13(2), 136-143. https://doi.org/ 10.4103/jioh.jioh 29120

[4] Bae, E. J., Kwon, H. J., \& Kwon, O. W. (2014). Changes in longitudinal craniofacial growth in subjects with normal occlusions using the Ricketts analysis. The Korean Journal of Orthodontics, 44(2), 77-87. https://doi.org/10.4041/ kjod.2014.44.2.77

[5] Belluzzo, R. H. L., Faltin, Jr. K., Ortolani, C., \& Chelotti, A. (2013). Correlation between transverse and vertical measurements in Brazilian growing patients, evaluated by Ricketts-Faltin frontal analysis. Dental press journal of orthodontics, 18, 5054. https://doi.org/10.1590/S2176-94512013000100013
0.6 were included, which were included in the second group depending on the indicators of the first group $\left(R^{2}=\right.$ from 0.691 to 0.834 ) and included in the third group depending on the indicators of the first and second groups $\left(R^{2}=\right.$ from 0.640 to 0.910$)$; in young women with a very wide type of face - respectively only $2\left(R^{2}=0.691\right.$ and 0.834$)$ and $5\left(R^{2}\right.$ = from 0.628 to 0.919$)$ models; in young women with a wide face type $-5\left(R^{2}=\right.$ from 0.606 to 0.854$)$ and $7\left(R^{2}=\right.$ from 0.607 to 0.888 ) models, respectively.

2 . Both young men and young women with a wide face type among the teleradiographic indicators of the first group included in the models of indicators of the second group according to the Ricketts method most often included ArGo distance (20.7 \% and $28.6 \%$, respectively), POr-NBa angle (13.8 \% and $14.3 \%$, respectively) and the ratio of $\mathrm{N}$ S:S-Ar' (10.3\% and $14.3 \%)$; as well as only for young men - distances N-S and S-E (10.3\% each).

3 . In young men with a wide type of face among the teleradiographic indicators of the first and second groups included in the models of indicators of the third group according to the Ricketts method most often included the angle N-CF-A (12.8\%), distance Ar-Go (10.3\%), distance $\mathrm{N}-\mathrm{CC}$ and A-NPog and angles ANS-Xi-Pm, POr-ANSPNS and DC-Xi-Pm (7.7 \% each); in young women with a very wide face type - distance Xi-Pm (18.2\%), distance P-PTV and angles MeGo-NPog and POr-CFXi (9.1\% each); in young women with a wide type of face - the distances ANPog and Xi-Pm and the angle NBa-PtG (10.3\% each).

The built-in regression models of teleradiography indicators used in the Ricketts method for young men and young women with orthognathic occlusion with different face types will allow to develop a computer program that will allow orthodontists to automatically calculate the required cephalometric parameters.

[6] Bolzan, G. D. P., Berwig, L. C., Prade, L. S., Weinmann, A. R. M., Moraes, A. B. D., \& Silva, A. M. T. D. (2014). Agreement between Anthropometry and cephalometry methods in classification of the facial type. Revista CEFAC, 16, 222-227. https://doi.org/ 10.1590/1982-0216201410012

[7] Bushan, M. H., Vasylenko, Z. S., \& Hryhoreva, L. P. (1990). Справочник по ортодонти [Handbook of orthodontics]. Кишенев: Картя Молдовеняскэ - Kishinev: Kartia Moldoveniaske.

[8] Chernysh, A. V. (2018). Regression models of individual cephalometric indicators used in the method of R. M. Ricketts. Biomedical and Biosocial Anthropology, 32, 56-62. https:// doi.org/10.31393/bba32-2018-08

[9] Dmitriev, M., Gunas, V., Polishchuk, S., Olkhova, I., \& Kumar, A. (2020). Modeling of Central Incisors Position Indicators in boys and girls according to CC. Steiner method for Forensic Dental Identification. The Official Publication of Indian Academy of Forensic Medicine, 42(3), 155-160. https://doi.org/10.5958/ 0974-0848.2020.00043.3

[10] Doroshenko, S. I., \& Kulginsky, Е. А. (2007). Основы телерентгенографоии [Fundamentals of teleradiography]. К.: Здоров'я - К.: Zdorovija.

[11] Drachevska, I. Yu., Dmitriev, M. O., Perera Clifford, Shevchenko, V. M., \& Gunas, I. V. (2020). Determination of cephalometric 
parameters, which usually do not change during surgical and orthodontic treatment depending on facial types in Ukrainian young men and young women with orthognathic occlusion. Biomedical and Biosocial Anthropology, 41, 18-23. doi: 10.31393/bba41-2020-03

[12] Gunas, I. V., Dmitriev, N. A., \& Marchenko, A. V. (2015). Methodological aspects of computed tomography odontomorphometry of boys and girls with the physiological bite. Journal of Education, Health and Sport, 5(11), 345-355.

[13] Gunas, V. I., Kotsyura, O. O., Babych, L. V., Shevchuk, Y. G., \& Cherkasova, O. V. (2020). Features correlations of the sizes of molars with cephalometric indicators of men of the western region of Ukraine. Reports of Morphology, 26(2), 51-61. https:/ /doi.org/10.31393/morphology-journal-2020-26(2)-08

[14] Gunas, V. I., Mishalov, V. D., Serebrennikova, O. A., Klimas, L. A., \& Shayuk, A. V. (2018). Palmar dermatoglyphics of modern Ukrainians: regional trends. Biomedical and biosocial anthropology, 31, 11-17. https://doi.org/10.31393/bba31-201802

[15] Ikenna Isiekwe, G., Olatokunbo daCosta, O., \& Chukwudi Isiekwe, M. (2012). A cephalometric investigation of horizontal lip position in adult Nigerians. Journal of orthodontics, 39(3), 160-169. https://doi.org/10.1179/1465312512Z.00000000026

[16] llyas, M., ul Hamid, W., \& Shaheen, A. (2012). Posteroanterior cephalometric norms in Pakistani adults. Pakistan Orthodontic Journal, 4(1), 10-16.

[17] Joshi, M., Wu, L. P., Maharjan, S., \& Regmi, M. R. (2015). Sagittal lip positions in different skeletal malocclusions: a cephalometric analysis. Progress in orthodontics, 16(1), 1-8. https://doi.org/10.1186/s40510-015-0077-x

[18] Marchenko, A. V., Petrushanko, T. O., Gunas, I. V., Serebrennikova, O., \& Trofimenko, Y. Y. (2017). Computertomographic characteristics of root length incisors and canines of the upper and lower jaws in boys and girls with different craniotypes and physiological bite. Wiadomosci Lekarskie, 70(3), 499-502. PMID: 28711896

[19] Marchenko, A. V., Shinkaruk-Dykovytska, M. M., Pozur, T. P., Gunas, V. I., \& Orlovskiy, V. O. (2020). Models of individual linear dimensions necessary for the construction of the correct form of dental arches in young men with a wide face, depending on the features of odontometric and cephalometric indicators. Wiadomosci lekarskie (Warsaw, Poland: 1960), 73(6), 11031107. PMID: 32723934

[20] Moroz, V. M., Sarafinyuk, L. A., \& Gunas, I. V. (2008). Age and sex characteristics of central hemodynamics in adolescence. Biomedical and biosocial anthropology, 10, 92-97.

[21] Muhammed, F. K., Abdullah, A. O., \& Liu, Y. (2019). Morphology, incidence of bridging, dimensions of sella turcica, and cephalometric standards in three different racial groups. Journal of Craniofacial Surgery, 30(7), 2076-2081. https:// doi.org/10.1097/SCS.0000000000005964

[22] Perez, I. E., Chavez, A. K., \& Ponce, D. (2011). Cephalometric norms from posteroanterior Ricketts' cephalograms from Hispanic Americans Peruvian non adult patients. Acta Odontologica Latinoamericana, 24(3), 265-271.

[23] Perez, I., Chavez, A. K., \& Ponce, D. (2016). Applicability of the Ricketts' posteroanterior cephalometry for sex determination using logistic regression analysis in Hispano American Peruvians. Journal of forensic dental sciences, 8(2), 111. https://doi.org/10.4103/0975-1475.186371

[24] Phulari, B. (2013). An atlas on cephalometric landmarks. JP Medical Ltd. doi: 10.5005/jp/books/11877

[25] Profit, W. R. (2017). Современная ортодонтия (4-е изд., пер. с англ.) [Modern orthodontics (4th ed., trans. from English)]. М.: МЕДпресс-информ - М.: MEDpress-inform.

[26] Ricketts, R. M. (1972). The value of cephalometrics and computerized technology. Angle Orthod., 42, 179-199. https:/ /doi.org/10.1043/0003-3219(1972)042\%3C0179: TVOCAC\%3E2.0.CO;2

[27] Siddika, A., Rahman, S. A., \& Alam, M. K. (2020). Ricketts' cephalometric analysis for Saudi population. Pesquisa Brasileira em Odontopediatria e Clinica Integrada, 20. https:/ /doi.org/10.1590/pboci.2020.059

[28] Sobon, J. S., Cherkasova, O. V., Gunas, V. I., Babych, L. V., \& Kotsyura, O. O. (2020). Correlations of linear sizes of molars with cephalometric indicators of practically healthy men of the southern region of Ukraine. Biomedical and Biosocial Anthropology, 38, 36-46. https://doi.org/10.31393/bba38-202006

[29] Suarez, H. F. C., Gonzalez, F. V., \& Gay, J. M. S. (2013). Ricketts' cephalogram norms observed in children from Matanzas. Revista Cubana de Estomatologia, 50(4), 388396.

[30] Suarez, H. F. C., Morales, D. V., Ravinal, L. E. P., Castillo, Y. G., \& Gonzalez, F. V. (2018). Confidence interval for the standards of the Ricketts summarized cephalogram in Cuban children. Revista Medica Electronica, 40(1), 35-47.

\section{РЕГРЕСІЙНІ МОДЕЛІ ІНДИВІДУАЛЬНИХ ТЕЛЕРЕНТГЕНОГРАФІЧНИХ ПОКАЗНИКІВ ЗА МЕТОДОМ RІСКЕТТS В УКРАЇНСЬКИХ ЮНАКІВ I ДІВЧАТ ІЗ РІЗНИМИ ТИПАМИ ОБЛИЧЧЯ}

Драчевська І. Ю.

Annotation. Аномалії зубо-щелепної системи є одними з найскладніших викликів сучасної ортодонтії, і відповідно вимагають застосування сучасних та доказових методів лікування. Для прогнозування результатів лікування та правильного планування ортодонтичних втручань надійним інструментом в руках ортодонта є цефалометричний аналіз за методом Ricketts. Важливим етапом успішного впровадження даного методу аналізу, є проведення дослідження з врахуванням етнічної приналежності, віку, статі та впливу типу обличчя на телерентгенографрічні показники вирахувані за даним методом. Мета дослідження - побудувати та провести аналіз регресійних моделей телерентгенографрічних показників, що використовуються в методиці Ricketts в українських юнаків і дівчат із ортогнатичним прикусом із різними типами обличчя. Телерентгенографрічне дослідження за методикою Ricketts проведено 49 юнакам і 76 дівчатам із ортогнатичним прикусом. Цефалометричний аналіз виконано за допомогою програмного забезпечення OnyхCеph ${ }^{3 T M}$, версії 3DPro, компанії Image Instruments $\mathrm{GmbH}$. Німеччина (ліцензія на програмне забезпечення № URSQ-1799). Розподіл на типи обличчя проводили за допомогою визначення морфологічного індексу Гарсона. Усі показники були розділені на три групи: до першої групи увійшли основні цефалометричні точки та вимірювання, що використовуються в сучасних цефалометричних аналізах Schwartz, Ricketts, Steiner, Roth-Jarabak, Burstone i Bjork i входять до параметрів, які зазвичай не змінюються під час хірургічного та ортодонтичного лікування; до другої групи - метричні зубо-щелепні характеристики за методом Ricketts яким хірургічними методами можна змінювати довжину, ширину, кути та положення щелеп; до третьої групи - показники за методом Ricketts які характеризують положення кожного окремого зуба відносно один одного, черепних структур та профрілю м'яких тканин обличя. Регресійні моделі індивідуальних телерентгенгографрічних показників побудовані за допомогою ліцензійного пакету "Statistica 6,0". Aналізу підлягали лише достовірні моделі з коефіцієнтом детермінації вищим 0,6. В юнаків із широким типом обличчя із 13 
можливих побудовано 9 моделей телерентгенографічних показників $\left(R^{2}=\right.$ від 0,691 до 0,834) які увійшли до другої групи в залежності від показників першої групи та 9 ( $R^{2}=$ від 0,640 до 0,910) із 15 можливих моделей показників які увійшли до третьої групи в залежності від показників першої та другої груп. В юнаків із широким типом обличчя до побудованих моделей показників які увійшли до другої групи в залежності від показників першої групи найбільш часто входять відстань Ar-Go (20,7 \%), кут POrNBa (13,8 \%), відстані N-S і S-E та співвідношення N-S:S-Ar' (по 10,3 \%); а до моделей показників які увійшли до третьої групи в залежності від показників першої та другої груп - кут N-CF-A (12,8 \%), відстань Ar-Go (10,3 \%), відстані N-CC і A-NPog та куm ANS-Xi-Pm, POr-ANSPNS i DC-Xi-Pm (по 7,7 \%). У дівчат із дуже широким типом обличчя із 13 можливих побудовано лише 2 моделі телерентаенографічних показників $\left(R^{2}=0,691\right.$ i 0,834) які увійшли до другої групи в залежності від показників першоі групи та 5 ( $R^{2}=$ від 0,628 до 0,919) із 15 можливих моделей показників які увійшли до третьої групи в залежності від показників першої та другої груп. У дівчат із дуже широким типом обличчя до побудованих моделей показників які увійшли до третьої групи в залежності від показників першої та другої груп найбільш часто входять відстань Xі-Pm (18,2 \%), а також відстань $P$ PTV mа кути MeGo-NPog і POr-CFXi (по 9,1\%). У дівчат із широким типом обличчя із 13 можливих побудовано 5 моделей телерентаенографічних показників ( $R^{2}=$ від 0,606 до 0,854) які увійшли до другої групи в залежності від показників першоі групи та 7 ( $R^{2}=$ від 0,607 до 0,888) із 15 можливих моделей показників які увійшли до третьої групи в залежності від показників першої та другої груп. У дівчат із широким типом обличчя до побудованих моделей показників які увійшли до другої групи в залежності від показників першої групи найбільш часто входять відстань Ar-Go (28,6 \%) та кут POr-NBa і співвідношення S-ar:ar-Go (по 14,3%), а до моделей показників, які увійшли до третьої групи в залежності від показників першої та другої груп - відстані A-NPog і Xi-Pm та кут NBa-PtG (по 10,3%).

Ключові слова: регресійний аналіз, телерентгенографрія, цефралометрія за методом Ricketts, юнаки та дівчата з ортогнатичним прикусом, типи обличчя. 